\title{
The role of microfinance institutions on poverty reduction in Ethiopia: the case of Oromia Credit and Saving Share Company at Welmera district
}

\author{
Dejene Adugna Chomen* (1)
}

\begin{abstract}
The purpose of this study is to assess the contribution of Oromia Credit and Saving Share Company microfinance institution on poverty alleviation in Welmera district, Oromia Special Zone Surrounding Finfine, Oromia Regional State, Ethiopia. Both random and purposive sampling techniques were used for data collection. Three hundred and fifty-seven respondents were selected from twelve different villages for the data collection. The study used a binary logistic regression to identify the key determinants of the income improvement of respondents. The findings confirmed that education level, voluntary saving, and utilization of loan for the intended purposes are statistically significant and positively contributed to the income improvement of the respondents in the study area. The finding revealed that most of the respondents' income improved after they joined the program which impacted positively in improving their standards of living.
\end{abstract}

Keywords: Microfinance, Poverty reduction, Binary logistic, Welmera, Ethiopia

\section{Introduction}

Initially, microfinance was introduced to the globe by Muhammad Yunus in 1976 in Jobra's village in Bangladesh [29]. It has currently been an effective instrument for poverty reduction [4]. However, the contribution of microfinance services in poverty reduction got more attention in 2005, after the United Nations (UN) announced the year of international microcredit. Many microfinance institutions have arisen and have attracted the poorer communities and have developed new strategies to realize their vision [29]. Since then, most developing countries have been using microfinance as the best strategy to eradicate poverty $[19,45]$.

\footnotetext{
*Correspondence: jinudejene123@gmail.com

Department of Business Economics, School of International Trade and Economics, University of International Business and Economics, Chaoyang District, Beijing 100029, China
}

Several microfinance institutions (MFIs) emerged in Africa to fulfill the limitless need for financial services and provide different benefits in the past decades. For instance, some of these microfinance institutions successfully address materials shortage, the tangible materials like goods, intangible (services) to realize them. Once properly managed, microfinancing's materials benefits can range beyond the household into the community [45]. However, some scholars describe that few of these microfinance institutions focus on offering loans, whereas others offer both credit facilities and gather the deposit[12].

In Ethiopia, microfinance was introduced in 1995 to reduce poverty, and since then, Ethiopia's government has stimulated the expansion of modern financial services in the country. Presently, around 31 licensed microfinance institutions are operating throughout the country [17]. In recent times, the government of Ethiopia developed various developmental strategies 
such as a poverty reduction strategy paper which is aimed at enhancing and supportable growth, among other documents, considered microfinance as the best reference in achieving the intended development objectives and limiting the risky trends in poverty problem and meeting the millennium development goals [46]. Normally, almost most of Ethiopia's microfinance institutions have common goals: poverty reduction by providing loans and saving services by using the group-approach lending system [20].

The Oromia Credit and Saving Share Company (OCSSCo) microfinance institution was introduced in the Oromia region in 1996 to deliver microfinance facilities (credit and saving) to the farmers in the rural areas in the region [44]. The OCSSCo microfinance institution is one of the country's biggest microfinance institutions in terms of loan provision and having a high number of customers [16].Many research findings in Ethiopia link microfinance to poverty reduction. For instance, Abebe [1] on the Specialized Financial Promotion Institute (SFPI) showed that after the households took the loan from the institution, their average monthly income increased and the intervention improved the beneficiaries' living standard. Similarly, a study of the Dedebit Credit and Saving Institution (DECSI) indicated that the institution contributed to the beneficiaries' financial and physical well-being (household consumption and housing improvement) [22].

Even though various studies were carried out to identify the importance of MFIs in reducing poverty in Ethiopia, to the best of the author's knowledge, this is the first research to access the contribution of microfinance institutions in poverty alleviation in this study area. Therefore, this research's broad aim is to assess the contribution of Oromia Credit and Saving Share Company in poverty reduction at Welmera district, Oromia Special Zone Surrounding Finfine, Oromia Regional State, Ethiopia.

This study has the following specific objectives: (1) to assess the contribution of microfinance on children's education enrollment and the saving attitude of the beneficiaries after they join the program and (2) to identify factors that determine the income improvement of the beneficiaries.

\section{Literature review}

Microfinance can be effective in poverty reduction if it is integrated with other developmental strategies that work to meet the poor's basic needs to take them from poverty [5, 32, 33]. Several studies in different disciplines used different approaches to assess the impacts of microfinance in poverty reduction. For instance, the interventions of the microfinance program influence social associations somewhat through their economic impacts. In various examples, credit systems implementers have demanded that the work leads to advanced social transformation, by authorizing women and shifting gender relations in the household and the community [2]. Likewise, Nichols [38] tried to conclude the influence of microfinance on the poor in China's rural areas. He found that microcredit had a range of positive impacts on a poor community in central China. A study done in Vietnam exhibited that after the beneficiaries joined the microfinance institutions, they saw significant progress in their beneficiaries' income and consumption [15]. Another study carried out in India revealed that the poor improve their microenterprises, smooth consumption, rise returns making ability, and appreciate a better quality of life because of microcredit's efficient provision [4].

In a panel data approach/framework, Khandker [30] investigate the relationship between microfinance and poverty for a sample size of 1,789 households drawn from 87 villages in 29 Thanas in Bangladesh and show that access to microfinance helped both poor female participants in the program and the local economy. The study confirms that there is evidence of reducing overall poverty decline at the community level. Research conducted in Pakistan also shows that microfinance programs have positively contributed to household expenditure and children's education [39]. Correspondingly, a study conducted in Zanzibar concluded that after the household became the microfinance institution customer, they could improve their income to expand their business [23].

Similarly, a report conducted in Nigeria confirmed that microfinance contributed to eradicating poverty among women after receiving loans by improving their economic status and social and political conditions [25]. Besides, participation in an MFI program empowers clients to change managing their enterprise ones [34]. Likewise, a study undertaken in Kenya showed that microfinance institutions could contribute to poverty reduction [40]. The study also actively exhibited the loan use helped the beneficiaries have their dairy farm and small retail shops. Correspondingly, research conducted by Chowdhury [13] and Abebe [1] found that the households' living conditions improved because of microfinance intervention. Contrary to these views, Mosley and Hulme [35] found that microfinance institutions' clients could not generate income for the poor sections of the people. Similarly, research conducted in Bangladesh suggested that no result to provision assertions that programs 
raise consumption level and/or the program's contribution that shows incremental education enrollment for children [33]. To sum up, extant works of literature are inconsistent and inconclusive. Furthermore, previous study works have not examined the role of Oromia Credit and Saving Share Company microfinance institution on poverty alleviation by targeting the study area. This study, therefore, intends to contribute to the literature by filling these gaps.

\section{Methods}

The study was carried out in Welmera District which is found in Oromia Special Zone Surrounding Finfine, Oromia Regional State, Ethiopia. The district's capital town Holeta is at a distance of $29 \mathrm{~km}$ to the west along the main road to Ambo from Addis Ababa (which is the capital city of the country). The district is bounded on the south by the Sebeta Hawas district, on the west by Ejere district, on the north by Mulo district, on the northeast by the Sululta district, on the east by the city of Burayu. The Welmera district comprises 23 rural villages and 3 towns.

\section{Data sources and sample size determination}

The study used several primary data collection methods like survey/questionnaire, direct observation, and key informant interviews (KII). The questionnaire was a combination of closed and open-ended questions. The choice of sampling size/designs depends on the type of research and the type of conclusion the researcher wants to draw[31]. To meet the objectives of this study, we have implemented both purposive and random sampling techniques. To select the respondents from the district through random sampling techniques, the first step was to identify the total number of villages known as beneficiaries of the institution using purposive sampling technique. Out of eighteen (18) villages, twelve (12) were selected from the district using a random sampling method. To select the required number of respondents, we applied random sampling. According to Neuman [37], a population size less than 1000 must take $30 \%$ a sample ratio. However, as Saunders (2005) cited in Muiruri [36], a sample is considered adequate if the sample size is greater than 30 and over $10 \%$ of the population.

In contrast to Neuman and Saunders, this study used $15 \%$ of the total population as a sample (see Table 1).
Table 1 Sample villages and sample size. Source: Author's Survey

\begin{tabular}{llllll}
\hline S. no. & $\begin{array}{l}\text { Name of } \\
\text { villages }\end{array}$ & Category & $\begin{array}{l}\text { Target } \\
\text { population }\end{array}$ & Sample & $\begin{array}{l}\text { \% of the } \\
\text { sample }\end{array}$ \\
\hline 1 & Nano Kersa & Beneficiaries & 274 & 41 & 15 \\
2 & Gole Liban & Beneficiaries & 396 & 59 & 15 \\
3 & Fale Tulu Rada & Beneficiaries & 140 & 21 & 15 \\
4 & Geba Kemisa & Beneficiaries & 431 & 64 & 15 \\
5 & Tulu Wato & Beneficiaries & 292 & 44 & 15 \\
& Dalecha & & & \\
6 & Nano Suba & Beneficiaries & 192 & 29 & 15 \\
7 & Geresu Sida & Beneficiaries & 201 & 30 & 15 \\
8 & Berfeta 1 & Beneficiaries & 74 & 11 & 15 \\
9 & Daho Lafto & Beneficiaries & 154 & 23 & 15 \\
10 & Wajitu Harbu & Beneficiaries & 58 & 9 & 15 \\
11 & Bekeka Kore & Beneficiaries & 71 & 11 & 15 \\
& Odo & & & & \\
12 & Telacho & Beneficiaries & 97 & 15 & 15 \\
Total & & & 2380 & 357 & 15 \\
\hline
\end{tabular}

\section{Model specifications}

Most of the time, the binary logistic regression framework depicts the connections between one or more independent variables as well as a binary outcome variable [18]. Furthermore, binary logistic regression is the most applicable model when the dependent variable is a dummy variable [43]. Thus, to identify the key factors for the beneficiaries' improvement in income, this study used binary logistic regression analysis.

The generalized linear model was written as follows:

$$
\begin{aligned}
Y= & B_{o}+B_{1} X_{1}+B_{2} X_{2}+B_{3} X_{3}+B_{4} X_{4}+B_{5} X_{5} \\
& +B_{6} X_{6}+B_{7} X_{7}+B_{8} X_{8}+B_{9} X_{9}+B_{10} X_{10}+\mu
\end{aligned}
$$

where $\mathrm{X}_{1}$ to $\mathrm{X}_{4}$ represents a quantitative/continuous independent variable and $X_{5}$ to $X_{10}$ stands for independent variables that are considered as a dummy and $\mu$ is the error term

$$
Y=\left\{\begin{array}{l}
1, \text { if income improved } \\
0, \text { otherwise }
\end{array}\right.
$$

Specifically, binary logistic regression was expressed as below:

$$
\begin{aligned}
Y & =\ln \left(\frac{p}{1-p}\right) \\
& =B_{0}+B_{1} X_{1}+B_{2} X_{2}+B_{3} X_{3}+\cdots B_{N} X_{N}
\end{aligned}
$$


where $Y$ is the probability of income improvement; $B_{0}$ is constant; and $B_{1} \ldots+B_{N}$ are parameters.

Thus, the model is specifically expressed as follows:

$$
\begin{aligned}
\mathrm{INIM} \operatorname{Pr}= & \beta o+\beta_{1} \text { age }+\beta_{2} \mathrm{fms}+\beta_{3} \mathrm{dwm}+\beta_{4} \mathrm{dfm}+\beta_{5} \mathrm{~s} \\
& +\beta_{6} \mathrm{tr}+\beta_{7} \mathrm{ul}+\beta_{8} \mathrm{~ms}+\beta_{9} \text { edus }+\beta_{10} \text { gend }
\end{aligned}
$$

where INIMPr stands for income improvement, and age,fms, dwm,dfm,s,tr,ul,ms, edus, and gend stand for age, family size, duration with microfinance, distance from the lending institution, saving, training, utilization of loan, marital status, education status, and gender, respectively (see Table 2). took the loan for purchasing agricultural inputs (such as fertilizer and improved seed (see Table 3). However, $16.5 \%$ of them used loans for animal fatting. But almost less than two (1.16\%) of the respondents used the loan for other (poultry production). Thus, this study confirms that most of the respondents in the study area used the loan to purchase agricultural inputs and animal fatting. Besides, the study tried to figure out whether the respondents used the loans for their intended purpose or not. A majority (94.67\%) of the respondents used the loan for the proposed purpose from the survey. However, a few respondents have used the loan for the unintended purpose

\begin{tabular}{|c|c|c|c|}
\hline Variables & Variable type & Variable description & Expected effect \\
\hline Income & Dummy & $1=$ improved and $0=$ otherwise & \\
\hline Saving & Dummy & $1=$ having voluntary saving and $0=$ otherwise & + \\
\hline Training & Dummy & $1=$ got training and $0=$ otherwise & + \\
\hline Utilization of loan & Dummy & $1=$ utilized for the intended purpose and $0=$ otherwise & + \\
\hline Marital status & Dummy & $1=$ married and $0=$ otherwise & + \\
\hline Education status & Dummy & $1=$ educated and $0=$ otherwise & + \\
\hline Gender & Dummy & $1=$ if male and $0=$ otherwise & - \\
\hline Age & Continuous & measured in years & + \\
\hline Family size & Continuous & Number of people in the family & - \\
\hline Duration with a microfinance institution & Continuous & Years in membership & + \\
\hline Distance from a lending institution & Continuous & How they far away from the microfinance institution (in km) & - \\
\hline
\end{tabular}

Table 2 Description of explanatory variables in the study. Source: Author's Design

\section{Results and discussion}

\section{Purpose of loan and loan usage of the respondents}

All beneficiaries took the loan from the institution to satisfy their unlimited needs. In this study, since all beneficiaries are farmers, they used the loan for agricultural and related activities. $51.26 \%$ of respondents (see Table 3). Some key informants also confirmed that some beneficiaries did not use the loan for the intended purpose; sometimes, they could not repay the loan. This shows that if the beneficiaries miss the loan's use for the intended purpose, they cannot improve their income and cannot repay the loan.

\begin{tabular}{|c|c|c|c|}
\hline Variables & Response & Frequency & Percentage \\
\hline \multirow[t]{8}{*}{ For what purpose did you use the loan? } & Children education & 40 & 11.2 \\
\hline & Animal fatting & 59 & 16.5 \\
\hline & Purchase of agricultural inputs & 183 & 51.26 \\
\hline & Medical expenses & 22 & 6.16 \\
\hline & Ceremonial expenses(wedding and funeral) & 27 & 7.56 \\
\hline & Small business & 22 & 6.16 \\
\hline & Others & 4 & 1.16 \\
\hline & Total & 357 & 100 \\
\hline \multirow[t]{3}{*}{ Did you use the loan entirely for the intended purpose? } & Yes & 338 & 94.67 \\
\hline & No & 19 & 5.33 \\
\hline & Total & 357 & 100 \\
\hline
\end{tabular}

Table 3 Respondents' loan purpose and usage. Source: Author's Survey 
Table 4 Income change and children education enrollment of the respondents after taking the loan. Source: Author's Survey

\begin{tabular}{llcl}
\hline Variables & Response & Frequency & Percentage \\
\hline $\begin{array}{c}\text { What is the status of } \\
\text { your income after }\end{array}$ & Increased & 287 & 80.39 \\
you took the loan? & Decreased & 34 & 9.52 \\
& Stayed the same & 36 & 10.08 \\
& Total & 357 & 100 \\
Did the loan you take & Yes & 246 & 69 \\
$\begin{array}{c}\text { help you to edu- } \\
\text { cate your children? }\end{array}$ & No & 111 & 31 \\
& Total & 357 & 100 \\
\hline
\end{tabular}

\section{Impacts of microfinance at the beneficiaries' level} Impacts on beneficiaries income

One of the measures of microfinance institution loan effectiveness is its ability to generate income for its beneficiaries. An increase in income can be a component of a better life. In other ways, the major objectives of microfinance are to help in generating income for low-income households and help in alleviating poverty. The majority of respondents' incomes were increased after they took loans from a microfinance institution (see Table 4). However, due to the improper use of the loan, the income of a few beneficiaries in the study area was decreased (see Table 4). Thus, as compared to before taking the loan, after they took a loan a large number of the respondents' income increased.

Besides, key informant's interviews also confirmed that the beneficiaries' status of income was improved after they took loans. Thus, it was found that the poor have undoubtedly benefited from the institution in several ways. From this, the study concluded that the microfinance institution has a great contribution to improve the living standards of the households in the study area. This result is confirmed with the previous studies done by Abebe [1] and Gutu and Mulugeta [21] in different parts of the country.

\section{Impacts on education}

A service provided to the beneficiaries is believed in one way or another way to promote the education status of children. This study observed that the beneficiaries' numbers of children attending school were increased after the beneficiaries joined the institution. As presented in the table above, $69 \%$ of the beneficiaries responded that after they took the loan, they could buy materials for their children and educate them as compared to before (see Table 4). From this, the results conclude that the OCSSCO microfinance brought an important influence on children's education enrollment which in turn helps to lift their families out of poverty. This study promotes the findings of Bantige [9]; Bhuiya [11], and Mosley and Rock [35], who found that the loan from microfinance help the respondents to give better education to their children. Correspondingly, another study that has been done on the Amhara Credit and Saving Institute (ACSI) in other regions of the country also points out that all beneficiaries in the study area could send their children to the school after the beneficiaries became the clients of the institution [6]. However, this finding converses with the finding of Banerjee et al. [7] which suggested that there is no change in the probability that children or teenagers are enrolled in school after the beneficiaries took the loan.

\section{Impacts on nutrition improvement}

Access to microfinance can create improvement in the nutritional intake of the beneficiaries and their families based on their effectiveness in the program. Regarding the improvement of food, the respondents were asked to reflect their responses about food diet improvement like increase consumption of food in the amount and variety. As stated in Table 5 from the total respondents, about 204 (57.14\%) gave their responses from strongly agree to agree that there is an increase in the quantity of consumption of food after they joined the program. However, about 153 (42.85\%) of the respondents don't agree with the improvement. Furthermore, about 192 (53.78\%) of the respondents gave their responses from strongly agree to agree for the existence of an increase in food in variety after they joined the institution.

Table 5 Nutritional improvements of the respondents after the program intervention. Source: Author's survey

\begin{tabular}{llll}
\hline Variables & Response & Frequency & Percent \\
\hline $\begin{array}{c}\text { Increase the consumption } \\
\text { of food in the amount }\end{array}$ & Strongly agree & 35 & 9.8 \\
& Agree & 169 & 47.33 \\
& Neutral & 114 & 31.93 \\
& Disagree & 39 & 10.92 \\
& Strongly disagree & - & - \\
& Total & 357 & 100 \\
Increase of food in a variety & Strongly agree & 17 & 4.76 \\
& Agree & 174 & 48.73 \\
& Neutral & 78 & 21.84 \\
& Disagree & 45 & 12.6 \\
& Strongly disagree & 25 & 7 \\
& Total & 357 & 100 \\
\hline
\end{tabular}


About 165 (46.22\%) gave their response regarding increase food in variety from neutral to strongly disagree (see Table 5).

This shows that how microfinance contributes to improving beneficiaries' food intake. Thus, since the beneficiaries' diet improved, it is possible to conclude that OCSSCo microfinance has an important role in reducing poverty by lifting the people from poverty. This result confirms another study done in the other region of the country by Doocy et al. [14], which indicated that microfinance programs have a significant influence on the improvement of nutritional position as well as on the well-being of the women participants and their families. Similarly, Ajit and Anu [4] report the same result.

\section{Impacts on the beneficiaries saving attitude}

In most cases, knowledge of microfinance improved attitude toward microcredit and the saving behavior of its beneficiaries [26]. Table 6 confirms that 236 (66.10\%) of the respondents responded that Oromia Credit and Saving Share Company (OCSSCo) has developed their culture of saving after they joined the institution. However, 121 (33.89\%) responded negatively. Correspondingly, research done by Gutu and Mulugeta [21] indicated improvement of profit, saving, and diet after the beneficiaries joined the institution. Furthermore, this study observed that about $87 \%$ of the beneficiaries know the benefit of credit and saving institutions on poverty reduction (see Table 6). From this, it is possible to conclude that most of the respondents have a good awareness of credit and saving and the benefit of the institution on poverty reduction. Thus, this indicates that OCSSCo had a major role to improve the saving habits of the beneficiaries which are the source of capital and finally a key for the economic development of the country.

\section{Training}

Training is very crucial to develop private outcomes and inclusive well-being for beneficiaries and to progress institutional consequences for the microfinance institutions [27]. In this regard, in addition to financial services, Oromia Credit and Saving Share Company provides nonfinancial services for the beneficiaries to build up their capacity. A positive response was obtained from the respondents which indicated about $96 \%$ of them got training from the institution especially on saving, loan utilization, and about the market and general training (see Table 7). Nevertheless, insignificant numbers of respondents $(4 \%)$ do not get training. Therefore, the study concludes that the given training helped the beneficiaries in adapting the behavior of saving and investing the loan in incomegenerating activities.

\section{Challenges of the beneficiaries to access the service}

Microfinance institutions in Ethiopia are facing many challenges in operating efficiently [10]. Similarly, the beneficiaries of microfinance institutions face various constraints and challenges. Concerning challenges and constraints, more than (29\%) of the beneficiaries said their great problem for accessing funds from this microfinance institution was the rate of interest they were charged for assessing funds (see Table 8). Likewise, a large share of the respondents also sees the distance from the lending institute $(26 \%)$ as another big challenge. Even though the two mentioned above are the major challenges, group lending, time of credit available, time of repayment, working ethics, and working time of the institute were also seen as challenges by the respondents in the study area (see Table 8). This study agrees with the study done by Sabit and Mohammed [42] on the same microfinance institution in the southwest part of the country.

Table 6 Respondents attitude about saving. Source: Author's Survey

\begin{tabular}{|c|c|c|c|}
\hline Items & Response & Frequency & Percent \\
\hline \multirow[t]{3}{*}{ Did you have a saving habit before you join this microfinance institution? } & Yes & 38 & 10.64 \\
\hline & No & 319 & 89.36 \\
\hline & Total & 357 & 100 \\
\hline \multirow[t]{3}{*}{ Did you have a saving habit after you join this microfinance? } & Yes & 236 & 66.10 \\
\hline & No & 121 & 33.9 \\
\hline & Total & 357 & 100 \\
\hline \multirow[t]{3}{*}{ Did you recognize microfinance's role in poverty reduction? } & Yes & 310 & 86.83 \\
\hline & No & 47 & 13.16 \\
\hline & Total & 357 & 100 \\
\hline
\end{tabular}


Table 7 Respondents about training. Source: Author's Survey

\begin{tabular}{llcl}
\hline Activities & Response & Frequency & Percentage \\
\hline Training is given & Yes & 343 & 96.07 \\
& No & 14 & 3.93 \\
& Total & 357 & 100 \\
Types of training & About market & 41 & 11.48 \\
& About saving & 172 & 48.18 \\
& Loan utilization & 109 & 30.53 \\
& General training & 35 & 9.50 \\
& Total & 357 & 100 \\
\hline
\end{tabular}

Table 8 Challenges of the respondents to access service. Source: Author's Survey

\begin{tabular}{lcc}
\hline Constraints and challenges & Frequency & Percent \\
\hline Time of credit availability & 31 & 8.68 \\
Time of repayment & 23 & 6.44 \\
Group lending & 69 & 19.32 \\
Amount of interest rate & 104 & 29.13 \\
Distance from the lending institute & 93 & 26.05 \\
Working time of the institute & 15 & 4.20 \\
Working ethics & 22 & 6.16 \\
Total & 357 & 100.0
\end{tabular}

\section{Econometric analyses}

\section{Result of multicollinearity test}

Multicollinearity problems will occur while two or more predictor variables in a multiple regression model are extremely interrelated [3]. As a measure of multicollinearity in the model, the variance inflation factor (VIF) and tolerance levels are used. It is an indication of multicollinearity when tolerance levels

Table 9 Multicollinearity test among explanatory variables. Source: Author's Survey

\begin{tabular}{lll}
\hline Variables & \multicolumn{2}{l}{ Collinearity Statistics } \\
\cline { 2 - 3 } & Tolerance & VIF \\
\hline Marital status & 0.888 & 1.127 \\
Gender & 0.944 & 1.059 \\
Education level & 0.943 & 1.061 \\
Family size & 0.440 & 2.272 \\
Voluntary saving & 0.891 & 1.122 \\
Age & 0.464 & 2.156 \\
Distance from lending institute & 0.915 & 1.093 \\
Training & 0.974 & 1.027 \\
Utilization of the loan & 0.881 & 1.134 \\
Membership duration & 0.890 & 1.123 \\
\hline
\end{tabular}

may be less than 0.40 and VIF is higher than 2.50 [3]. Therefore, as it is observed from Table 9, the model has no multicollinearity problem (see Table 9 ).

\section{Test of goodness fit and model summary}

The goodness-of-fit tests can be utilized when our data are discrete or continuous data and the final incorporating grouped continuous data through addition [24]. Most of the time, the Hosmer-Lemeshow goodness-of-fit test is the most appropriate and often used for binary logistic regression models [18]. To say the model is statistically fit to describe data, our $p$-value must be insignificant. Consequently, the below table shows that $\psi^{2}\left(\mathrm{df}=8, N=357, X^{2}=8.800\right)$ and its $p=0.359$ which is a more than $5 \%$ significance level (see Table 10). Furthermore, the Omnibus test of the model coefficient in the last iteration reveals that

Table 10 Hosmer and Lemeshow test and model summary. Source: Author's Survey

\begin{tabular}{lrrr}
\hline Test results & \multicolumn{1}{c}{$\boldsymbol{X}^{\mathbf{2}}$} & d.f & $\boldsymbol{P}$-value \\
\hline Hosmer-Lemeshow Goodness-of-fit test & 8.800 & 8 & 0.359 \\
Omnibus Test & 175.358 & 10 & 0.000 \\
Nagelkerke R Square & 0.617 & & \\
Classification table (overall percentage) & $89.7 \%$ & & \\
\hline
\end{tabular}

the addition of each variable into the model is statistically significant when $p=0.000$, which is less than that of a cutoff value of 0.05 . Moreover, the share of the total variation of the dependent variable is measured using Nagelkerke R Square. Accordingly, Nagelkerke $\mathrm{R}$ Square indicated that the model described around $61.7 \%$ of the variation in the data (see Table 10). Likewise, the predictive correctness of the model was calculated using the classification table. Thus, the study suggested that the overall percentage of correction of prediction was $89.7 \%$ (see Table 10 ).

\section{Result of the binary logistic regression}

The binary logistic regression is specified as a more exact and effective estimation system due to its capacity to provide the essential binary nature of the combination of the dependent variable [41]. Additionally, it allows the estimate of group association when independent variables are continuous, discrete, or both [8]. Table 11 reveals the logistic regression coefficient results, such as the standard errors, $\operatorname{Exp}(\beta)$, Wald test statistics, $p$-value for each predictor. Accordingly, the statistical significance and the result of each of the predictor variables are described in Table 11. 
Table 11 The output of binary logistic regressions. Source: Author's Survey

\begin{tabular}{|c|c|c|c|c|c|}
\hline Variables & Coefficients & S.E & Wald & Sig & $\operatorname{Exp}(B)$ \\
\hline Maritalstat(1) & -18.230 & $12,260.671$ & 0.000 & 0.999 & 0.000 \\
\hline Gender(1) & -0.916 & 0.510 & 3.222 & $0.073^{*}$ & 0.400 \\
\hline Education level(1) & 2.036 & 0.488 & 17.385 & $0.000^{* * *}$ & 7.658 \\
\hline Family size & -0.170 & 0.152 & 1.246 & 0.264 & 0.844 \\
\hline Voluntary saving(1) & 0.853 & 0.404 & 4.472 & $0.034^{* *}$ & 2.348 \\
\hline Age & 0.054 & 0.038 & 2.069 & 0.150 & 1.056 \\
\hline Distance from a lending institute & -0.093 & 0.043 & 4.708 & $0.030^{* *}$ & 0.911 \\
\hline Training(1) & 2.651 & 1.019 & 6.769 & 0.199 & 7.321 \\
\hline Utilization of loan(1) & 4.162 & 0.553 & 56.597 & $0.000^{* * *}$ & 64.169 \\
\hline Membership duration & 0.159 & 0.148 & 1.166 & 0.280 & 1.173 \\
\hline Constant & 36.990 & $15,110.789$ & 0.000 & 0.998 & $1.161 E+16$ \\
\hline
\end{tabular}

$* * * * * * *$ indicates that the level of significance at $1 \%, 5 \%$, and $10 \%$, respectively

Therefore, from Table 11, gender, education level, having voluntary savings, distance from the lending institute, and utilization of loans for intended purposes are determinants of income improvement. Gender has a significant effect on beneficiaries' income improvement: In the above table, gender (1) the reference category (1) shows males. The negative B (coefficient of the independent variable) shows that the probability of income improvement decreases from male to the next gender: while the probability of the next gender, female household 0 in income improvement increases by 0.400 (see Table 11). This is because females are more savers and take care of the risk than males. Educated people (literate) will have the probability of income improvement by 7.658 times more than illiterate. This is because educated persons can use the loan properly as stated on their plan than illiterate groups. They have a better understanding of how to invest the loan in income-generating activities than those uneducated groups.

Beneficiaries who have voluntary savings have a chance of income improvement by 2.348 than those without voluntary savings (see Table 11). This is because more savings will bring more opportunities to investments in income-generating activities which help them in income improvement. This result confirmed the country's study by Kebede and Menza [28], which found that the total number of voluntary and savers increases from year to year. Besides, this study tried to look at the utilization of the loan. Utilization of the loan for the intended purposes helped those who used the loan accordingly more than those who not used the loan for the intended purposes by 64.169. However, the study shows that as the distance from financial institutions increases by one unit, the improvement of beneficiaries' income decreases by 0.91 (see Table 11). This is because as beneficiaries far away from the lending institution, they lack access to market and information, and even they are not getting regular supervision from the institution compared to those living nearest to the institution.

\section{Conclusion}

In this study, we targeted at evaluating the role of microfinance institutions in poverty reduction in Ethiopia by taking Oromia Credit and Saving Sharing Company (OCSSCo) as an example. This study points out that the intervention of OCSSCo in the study area helped the beneficiaries improve their level of living conditions. The study discovered that after the beneficiaries joined the institution, their income increased, nutrition intake improved, and most beneficiaries could buy necessary items and materials to educate their children. Besides these, the bulk of the beneficiaries argued that they developed the habit of voluntary savings after they joined the institution. This implies that the microfinance institutions made efforts to increase the beneficiaries' income by putting proper monitoring and follow an up system in place. However, regardless of these achievements, most of these microfinance beneficiaries in the study area strongly disagree with the institution's rate of interest when they take loans'.

From the binary logistic regression result, the study concluded that education level, gender, distance from the lending institute, utilization of the loan for the intended purposes, and voluntary savings are significant in the model to determine income improvement of the beneficiaries. In contrast, other explanatory variables like age, family size, marital status, membership duration with the institution, and training with income improvement are not as strong. So, they do not significantly affect income improvement. This study concludes that Oromia Credit and Saving Share Company microfinance positively impacted 
beneficiaries' living conditions. This study recommends that to change many peoples' lives; the institution has to reduce the interest rate charged to the respondents when accessing financial products.

\section{Abbreviations}

ACSI: Amhara Credit and Saving Institute; DECSI: Dedebit Credit and Saving Institutions; MFIs: Microfinance institutions; OCSSCO: Oromia Credit and Saving Share Company; VIF: Variance inflation factor; SFPI: Specialized Financial and Promotion Institution; KII: Key informant interviews; UN: United Nations.

\section{Acknowledgements}

Not applicable.

\section{Authors' contributions}

DAC made all the contributions in writing of this manuscript. The author read and approved the final manuscript.

\section{Funding}

This study did not receive specific funding.

\section{Availability of data and materials}

On request, the author can provide the data used for this study.

\section{Declarations}

\section{Competing interests}

The author declares that there are no competing interests.

Received: 2 February 2021 Accepted: 12 July 2021

Published: 26 October 2021

\section{References}

1. Abebe T (2006) Impact of microfinance on poverty reduction in Ethiopia, the case of three branches of Specialized Finance and Promotional Institution(SFPI): Addis Ababa University, Masters Thesis, Ethiopia

2. Ackerly BA (1995) Testing the tools of development: credit programmes, loan involvement, and women's empowerment. IDS Bull 26(3):56-68

3. Adeboye N, Fagoyinbo IS, Olatayo T (2014) Estimation of the effect of multicollinearity on the standard error for regression coefficients. IOSR J Math 10(4):16-20

4. Ajit KB, Anu B (2012) Microfinance and poverty reduction in India. Integr Rev J Manag 5(1):31-35

5. Alemu KT (2008) Microfinance as a strategy for poverty reduction: a comparative analysis of ACSI and wisdom microfinance institution in Ethiopia. Master Theis, The Netherlands, 1-57

6. Asmamaw YC (2014) Impact of microfinance on living standards, empowerment and poverty alleviation of poor people in Ethiopia. J Field Actions 5:43-67

7. Banerjee A, Duflo E, Glennerster R, Kinnan C (2015) The miracle of microfinance? Evidence from a randomized evaluation. Am Econ Appl Econ 7(1):1-53

8. Barbara GT, Linda SF (2012) Using multivariate statistics. In: California State University, Northridge: Vol. Fifth Edit

9. Batinge BK (2014) An assessment of the impact of microfinance on the rural women in North Ghana. Eastern Mediterranean University

10. Beklentileri ZV, Alemu S (2018) The performance of Ethiopian microfinance institutions, challenges and prospects. Karadeniz Teknik Üniversitesi Sosyal Bilimler Enstitüsü Sosyal Bilimler Dergisi 8(16):307-324
11. Bhuiya M (2016) Impact of microfinance on health, education, and income of rural households: evidence from Bangladesh. Master Thesis, University of Dhaka, Bangladesh

12. Blavy R, Basu A, Yülek MÂ (2004) Microfinance in Africa: experience and lessons from selected African Countries. IMF Working Papers 04(174):1-23

13. Chowdhury A (2009) Microfinance as a poverty reduction tool-a critical assessment. DESA Working Paper No. 89, 1-13

14. Doocy S, Teferra S, Norell D, Burnham G (2005) Credit program outcomes: coping capacity and nutritional status in the food insecure context of Ethiopia. Soc Sci Med 60(10):2371-2382

15. Duong HA, Nghiem HS (2014) Effects of microfinance on poverty reduction in vietnam : a pseudo-panel data analysis. J Acc Finance Econ 4(2):58-67

16. Ebisa D, Getachew N, Fikadu M (2013) Filling the breach: microfinance. J Bus Econ Manag 1(1):10-17

17. Eshete $A$ (2010) Assessment of the role of microfinance Institutions in urban poverty Alleviation. Addis Ababa University, Master Thesis

18. Fagerland MW, Hosmer DW (2012) A generalized Hosmer-Lemeshow goodness-of-fit test for multinomial logistic regression models. Stata J 12(3):447-453

19. García-Pérez I, Fernández-Izquierdo MÁ, Muñoz-Torres MJ (2020) Microfinance institutions fostering sustainable development by region. Sustainability (Switzerland) 12(7):1-23

20. Gobezie G (2009) Sustainable rural finance: prospects, challenges, and implications. Int NGO J 4(2):012-026

21. Gutu F, Mulugeta W (2016) The role of microfinance on women's economic empowerment in Southwest Ethiopia. Glob J Manag Bus Res B Econ Commerce 16(6):1-10

22. Guush B, Cornelis G (2011) Does microfinance reduction rural poverty? Evidence-based on household panel data from Northern Ethiopia. Am J Agric Econ 93:43-55

23. Haji YH (2013) The contribution of microfinance institutions to poverty reduction at south District in Zanzibar. The Open University of Tanzania

24. Haschenburger JK, Spinelli JJ (2005) Assessing the goodness-offit of statistical distributions when data are grouped. Math Geol 37(3):261-276

25. Irobi CN (2008) Microfinance and poverty alleviation. A case of Obazu Progressive Women Association Mbieri, Imo State -Nigeria. Master Thesis, SLU

26. Jebarajakirthy C, Lobo A, Hewege C (2015) Enhancing youth's attitudes towards microcredit in the bottom of the pyramid markets. Int J Consum Stud 39(2):180-192

27. Karlan D, Valdivia M (2006) Teaching entrepreneurship: impact of business training on microfinance clients and institutions. Yale University, Center Discussion Paper No.941, 1-46

28. Kebede Menza S, Kebede T (2016) The impact of microfinance on household saving: the case of amhara credit and saving institution feres bet Sub-Branch, Degadamot Woreda. J Poverty J 27:64-82

29. Khan M, Rahaman MA (2007) Impact of microfinance on living standards, empowerment and poverty alleviation of poor people: a case study on microfinance in the Chittagong District of Bangladesh. Umea School of Business, Master Thesis, 5(13), 1-95

30. Khandker SR (2005) Microfinance and poverty: evidence using panel data from Bangladesh. World Bank Econ Rev 19(2):263-286

31. Kothari C (1990) Research methodology: methods and techniques ((Second Re). New Age International Publishers

32. Lakwo A (2006) Microfinance, rural livelihoods, and women's empowerment in Uganda. In African Studies Centre

33. Morduch J (2000) The microfinance schism. Princeton University, New Jersey, USA. World Development, 28(4), 617-629

34. Morris G, Barnes C (2005) An assessment of the impact of microfinance: a case study from Uganda. J Microfinance 7(1):40-54

35. Mosley P, Rock J (2004) Microfinance, labor markets and poverty in Africa: a study of six institutions. J Int Dev 16(3):467-500

36. Muiruri PM (2014) The role of micro-finance institutions to the growth of micro and small enterprises (MSE) in Thika, Kenya (Empirical Review of Non- Financial Factors). Int J Acad Res Acc Finance Manag Sci 4(4):249-262 
37. Neuman WL (2014) Social research methods: qualitative and quantitative approaches (Seventh Ed)

38. Nichols S (2004) A case study analysis of the impacts of microfinance upon the Lives of the Poor in Rural China.RMIT University,Melbourne, Australia

39. Noreen U, Imran R, Zaheer A, Saif MI (2011) Impact of microfinance on poverty : a case of Pakistan. World Appl Sci J 12(6):877-883

40. Okibo BW, Makanga N (2014) Effects of microfinance institutions on poverty reduction in Kenya. Int J Curr Res Acad Rev 2(2):76-95

41. Owolabi OE (2015) Microfinance and poverty reduction in Nigeria: A case study of LAPO microfinance bank: The University of Leeds. Ph.D. Dissertation, 1-235

42. Sabit J, Mohammed A (2015) Role of credit and saving share company in poverty reduction in rural communities of Gumay District, Jimma Zone, South West Ethiopia. Int J Appl Econ Finance 9(1):15-24

43. Santoso DB (2016) Credit accessibility: the impact of microfinance on rural indonesian households. Master Thesis

44. Tiruneh TB (2015) A comprehensive examination of the sustainability status of microfinance institutions in Ethiopia. Eur J Bus Manag 7(19):17-31
45. United Nations (2006) Microfinance in Africa: combining the Best Practices of Traditional and Modern Microfinance Approaches towards Poverty Eradication

46. Wolday A (2004) Managing growth of microfinance institutions (MFI S): Balancing sustainability and reaching a large number of clients in Ethiopia. Ethiopian J Econ XIII(2):62-102

\section{Publisher's note}

Springer Nature remains neutral with regard to jurisdictional claims in published maps and institutional affiliations.

Dejene Adugna Chomen is currently a Ph.D. student at the University International Business and Economics, School of International Trade and Economics, Department of Business Economics, China.

\section{Submit your manuscript to a SpringerOpen ${ }^{\circ}$ journal and benefit from:}

- Convenient online submission

- Rigorous peer review

- Open access: articles freely available online

- High visibility within the field

- Retaining the copyright to your article

Submit your next manuscript at $\boldsymbol{\nabla}$ springeropen.com 